\title{
Prevalence of mastitis in dairy cows from smallholder farms in Zimbabwe
}

\author{
Authors: \\ Simbarashe Katsande ${ }^{1}$ \\ Gift Matope ${ }^{1}$ \\ Masimba Ndengu ${ }^{2}$ \\ Davies M. Pfukenyi \\ Affiliations: \\ ${ }^{1}$ Department of Paraclinical \\ Veterinary Studies, University \\ of Zimbabwe, Zimbabwe \\ ${ }^{2}$ Department of Clinical \\ Veterinary Studies, University \\ of Zimbabwe, Zimbabwe \\ Correspondence to: \\ Davies Pfukenyi \\ Email: \\ dmpfukenyi@vet.uz.ac.zw \\ Postal address: \\ PO Box MP 167, Mount \\ Pleasant, Harare, Zimbabwe \\ Dates: \\ Received: 27 Sept. 2012 \\ Accepted: 28 Jan. 2013 \\ Published: 28 Mar. 2013 \\ How to cite this article: \\ Katsande, S., Matope, G., \\ Ndengu, M. \& Pfukenyi, \\ D.M., 2013, 'Prevalence \\ of mastitis in dairy cows \\ from smallholder farms in \\ Zimbabwe', Onderstepoort \\ Journal of Veterinary \\ Research 80(1), Art. \#523, \\ 7 pages. http://dx.doi. \\ org/10.4102/ojvr.v80i1.523

\section{Copyright:} \\ C 2013. The Authors. \\ Licensee: AOSIS \\ OpenJournals. This work \\ is licensed under the \\ Creative Commons \\ Attribution License. \\ Read online:

A cross-sectional study was conducted to determine the prevalence of sub-clinical and clinical mastitis and the associated factors in cows from selected smallholder dairy farms in Zimbabwe. Physical examinations were conducted on all lactating cows for evidence of signs of clinical mastitis. Composite milk samples were collected from all lactating cows for bacterial culture and somatic cell counting. Cows were categorised as clinical if they exhibited clinical features of mastitis, or sub-clinical if no apparent signs were present but they had a positive bacterial isolation and a somatic cell count of at least $300 \times 10^{3}$ cells $/ \mathrm{mL}$. Farm-level factors were obtained through a structured questionnaire. The association of mastitis and animaland herd-level factors were analysed using logistic regression. A total of 584 animals from 73 farms were tested. Overall, 21.1\% (123/584) had mastitis, 16.3\% (95/584) had sub-clinical mastitis and 4.8\% (28/584) had clinical mastitis. Herd-level prevalence was 49.3\%. Coagulasenegative staphylococci (27.6\%), Escherichia coli (25.2\%), Staphylococcus aureus (16.3\%), Klebsiella spp. (15.5\%) and Streptococcus spp. (1.6\%) were the most common isolates. In individual cows, pure dairy herds $(\mathrm{OR}=6.3)$ and dairy crosses $(\mathrm{OR}=3.1)$ were more likely to have mastitis compared to Mashona cows. Farms that used pre-milking teat dipping were associated with reduced mastitis prevalence. Further research is needed on the prevalence of mastitis and a comparison of data for both smallholder and commercial dairy farms in all regions of Zimbabwe should be undertaken.

\section{Introduction}

In Zimbabwe, smallholder dairy farming developmental programmes were initiated in 1983 (Ngongoni et al. 2006; Muchenje et al. 2007). Their contribution to national-marketed milk increased gradually from 2\% in 1998 and to an estimated 5\% in 2002 (Ngongoni et al. 2006). Smallholder dairy farming has the potential to increase the milk production base of the country, improve household nutrition and empower rural communities with income-generating ventures. It can assist farmers to diversify, lessen farming risks and create an opportunity for use of idle forage (Ngongoni et al. 2006).

Shortage of and poor quality fodder have been reported to be two of the major limiting factors to smallholder dairy farming in the country (Ngongoni et al. 2007). Mastitis is another major limiting factor; it is a disease of dairy cattle that causes low milk production and high economic losses (Ericsson-Unnerstad et al. 2009; Tesfaye, Regasa \& Kelay 2009). Mastitis is an inflammation of the mammary gland that is mostly caused by infectious agents, especially bacteria, but it can also be due to physical or chemical agents. Somatic cell counts (SCC) in milk are commonly used as indicators of mastitis, on the basis that an increase reflects an immune response to the presence of infection in the mammary gland (Green et al. 2008). Mastitis is associated with high SCC; this is mostly due to increased leukocyte levels, as they are involved in the removal of the infectious agents, and also exfoliated epithelial cells (Bagnicka et al. 2011). Leukocytes are responsible for destroying bacteria, and the enzymes left behind during the phagocytic process significantly reduce the shelf life of milk and milk products (Ingalls 2009). However, animals with low SCC can also have the mastitis pathogen present. Demands by consumers and processors for safe, high-quality dairy products are major factors in motivating the need for additional improvements in mastitis control in dairy herds. Mastitis could be reduced by improving milking procedures and hygiene in the herd (Karimuribo et al. 2008; Kivaria, Noordhuizen \& Msami 2007). Dry cow treatment, milking technique, post-milking teat dipping and antimicrobial treatment of clinical mastitis are examples of management factors that have a significant effect on the reduction of mastitis cases and bulk tank milk SCC (Lievaart, Barkema, Hogeveen \& Kremer 2009; Lievaart et al. 2009).

In Zimbabwe, there is little current information about the prevalence of mastitis, factors associated with mastitis and the bacteria mainly responsible for intra-mammary infections in the smallholder dairy sector. The only data that is available is from studies that were conducted more than a 
decade ago (Perry et al 1987; Makaya, Aarestrup \& Olsen 1996; Kudinha \& Simango 2002). Therefore, the objectives of this study were to determine (1) the individual animal- and herd-level prevalence and factors associated with mastitis and (2) the most common bacteria associated with subclinical and clinical mastitis in cows from smallholder dairy farms in Zimbabwe.

\section{Materials and methods \\ Study sites and selection of study sites}

A convenient sample of smallholder dairy farms $(n=73)$ in Zimbabwe was selected. Selection was based on the presence of farms that were producing and selling milk to milk-collecting centres when the study commenced, and on agro-ecological regions and locations of the areas.

The four selected smallholder dairy centers were: Dowa $\left(18^{\circ} 32^{\prime} \mathrm{S}, 32^{\circ} 07^{\prime} \mathrm{E}\right)$ in agro-ecological region IIA; Guruve $\left(16^{\circ} 20^{\prime} \mathrm{S}, 30^{\circ} 35^{\prime} \mathrm{E}\right)$ and Marirangwe $\left(18^{\circ} 06^{\prime} \mathrm{S}, 30^{\circ} 48^{\prime} \mathrm{E}\right)$ both in agro-ecological region IIB; and Nharira $\left(19^{\circ} 15^{\prime} \mathrm{S}\right.$, $31^{\circ} 15^{\prime} \mathrm{E}$ ) in agro-ecological region III.

\section{Study animals}

Animal ownership by the smallholder dairy farmers and the demographics of cows sampled are presented in Table 1. All smallholder dairy farms in the respective study areas with at least a single lactating cow were recruited to the study. A total of 73 smallholder farmers were still operational when the study commenced. The average herd size per farm ranged from 10 to 16 , with a median of 13 animals. The breeds kept by these farmers included the local indigenous Sanga type (Bos indicus) commonly known as 'Mashona', exotic dairy breeds (Bos taurus), such as Red Dane and Jersey, dairy crosses, such as Friesian, Jersey and Red Dane crosses, and beef crosses, such as Brahman, Hereford and Mashona crosses. All of the lactating cows $(n=584)$ on the selected farms were eligible for milk sample collection. A total of 584 lactating cows were sampled with most being the local indigenous Mashona breed (44\%) and dairy crosses (43.7\%), whilst a few were pure dairy $(2.4 \%)$ and beef crosses $(9.9 \%)$. Due to the unavailability of records, the exact ages and milk production levels of the sampled cows was not determined. However, the parity of the cow was recorded.

\section{Assessment of milking practices}

A pre-tested structured questionnaire with close-ended questions was used to collect data on milking practices and other farm management variables thought to influence the prevalence of mastitis in smallholder dairy cows. These factors included milking procedures, milking place and frequency of milking, cleaning and drying methods of teats, source of water (open or closed source), pre-and post-milking teat dipping and milking practices for suspected mastitic cows. The questionnaire was administered through a faceto-face interview. The pre-testing of the questionnaire was carried out on a few selected farmers who farmed in one of the study areas; clarity of questions and its user friendliness was checked and later revised. The survey was carried out between November 2009 and March 2010.

\section{Milk sample collection and clinical examination}

The collection of milk samples for bacterial culture and somatic cell counting was carried out during the same period as the questionnaire survey. Teats were washed using clean running water, wiped dry with disposable paper towels and disinfected using 70\% ethyl alcohol. To minimise contamination with bacteria from the skin around the teat canal, the first streams of milk were discarded. Composite quarter milk samples were collected aseptically from all lactating cows and were transported to the laboratory in cooler boxes on ice (approximately $4{ }^{\circ} \mathrm{C}$ ) where milk samples were plated out and preparations for microscopic cell count commenced on the day of sampling. A thorough physical examination for evidence of clinical mastitis was conducted on all lactating cows that were sampled in this study. Clinical findings such as secretions, abnormalities of size and shape of the udder, its consistency and temperature were assessed by visual inspection and palpation. A cow was considered to have clinical mastitis if it fulfilled at least two of the clinical findings, (1) pain reaction upon palpation, (2) changes in colour and consistency of milk (blood tinged milk, watery secretions, clots, pus) and (3) change in consistency of the udder (Lakew, Tolosa \& Tigre 2009). Cows that did not have clinical mastitis were tested further for sub-clinical mastitis based on culture and somatic cell counting. A cow showing no apparent clinical signs of mastitis and whose milk was macroscopically normal, but had a positive bacterial culture and SCC of at least $300 \times 10^{3}$ cells/mL (International Dairy Federation 1987), was regarded as positive for sub-clinical mastitis.

\section{Laboratory tests}

All the tests for bacterial culture and isolation were performed at the Central Veterinary Laboratory in Harare. Milk samples were cultured for bacteria as described by Haltia et al. (2006). All samples were plated on blood agar

TABLE 1: Smallholder farmers' cattle ownership and demographics of sampled cows.

\begin{tabular}{|c|c|c|c|c|c|c|c|c|c|}
\hline \multirow{2}{*}{$\begin{array}{l}\text { Study } \\
\text { area }\end{array}$} & \multirow{2}{*}{$\begin{array}{l}\text { Number of } \\
\text { farmers }\end{array}$} & \multicolumn{3}{|c|}{ Herd size } & \multicolumn{5}{|c|}{ Number of lactating cows sampled } \\
\hline & & $\begin{array}{l}\text { Total Number } \\
\text { Cattle }\end{array}$ & Median & Range & Mashona (\%) & Dairy (\%) & Dairy crosses $(\%)$ & Beef crosses (\%) & Total \\
\hline Marirangwe & 23 & 269 & 10 & $4-21$ & 39 & 12 & 106 & 13 & 170 \\
\hline Guruve & 23 & 356 & 14 & $4-33$ & 132 & 2 & 86 & 26 & 246 \\
\hline Dowa & 13 & 210 & 16 & $4-24$ & 35 & 0 & 21 & 10 & 66 \\
\hline Total & 73 & 998 & 13 & 4-33 & $257(44.0)$ & $14(2.4)$ & 255 (43.7) & $58(9.9)$ & 584 \\
\hline
\end{tabular}


(Oxoid, Basingstoke, Hampshire, UK), MacConkey agar (Oxoid) and Edward's agar (Oxoid) to detect most aerobic pathogens, enteric bacteria and streptococci respectively. The plates were incubated aerobically at $37{ }^{\circ} \mathrm{C}$ for up to $48 \mathrm{~h}$. A milk sample was considered positive for mastitis pathogen(s) if at least a single colony of a potential pathogen was detected and positively identified by biochemical tests. Plates showing mixed and confluent growths, with no evidence of single discernible colonies, were not investigated further. Primary identification of staphylococci was based on colony morphology, catalase test, Gram-staining morphology and differentiated from micrococci on the basis of the oxidativefermentative (OF) test carried out on semi-solid OF medium (Difco, Becton, Dickinson and Company, Franklin Lakes, NJ, USA). The staphylococci were also tested for production of coagulase enzyme by the tube method as described by Quinn et al. (1994). Isolates that produced Gram-positive cocci in clusters, and were catalase positive, glucose-fermentative, resistant to bacitracin and did not produce coagulase were identified as coagulase-negative staphylococci (CNS). Staphylococcus aureus isolates were differentiated from other coagulase-positive staphylococci (Staphylococcus intermedius and some strains of Staphylococcus hyicus) on the basis of mannitol fermentation on mannitol salt agar (Oxoid), susceptibility to $5 \mu \mathrm{g}$ novobiocin and 300 units of polymixin B as reported by Kudinha and Simango (2002). The enteric bacteria were identified using colony morphology, oxidase test, lactose fermentation on MacConkey agar (Oxoid), indole production test, citrate utilisation, and other standard biochemical tests as described by Quinn et al. (1994).

Somatic cell counts (SCC) were carried out in the Bacteriology Laboratory of the Central Veterinary Laboratory in Harare. The SCC were determined by using the Breed's direct smear method; spreading $0.1 \mathrm{~mL}$ of milk to cover about $1 \mathrm{~cm}^{2}$ of a glass slide, drying and staining with methylene blue (Quinn et al. 1994). The somatic cells were counted microscopically over approximately 50 fields under oil immersion for each sample, and the total number of cells was recorded using a counter. The counts were converted to the total number of somatic cells per $\mathrm{mL}$ using the formula suggested by Quinn et al. (1994).

\section{Data analysis}

The proportion of mastitis-positive cows was calculated against the total number of animals investigated; this was based on the clinical features of mastitis (clinical mastitis), the pathogen isolated and a SCC of at least $300 \times 10^{3} / \mathrm{mL}$ (sub-clinical mastitis). The prevalence of mastitis in individual cows was calculated according to the study area, breed, parity and history of mastitis. A herd was denoted as positive for mastitis if at least a single animal with mastitis (either clinical or sub-clinical) was detected. The farm-level prevalence of mastitis was calculated according to the study area and milking management practices, such as the use of pre- and post-milking teat dipping, milking frequency, cleaning of teats prior to milking, use of disposable paper towels, and source of water (open or closed source) for milking. The association between mastitis $(0=$ negative and 1 = positive) and categorical animal- and farmlevel variables was assessed in univariable analyses using Fisher's exact $\mathrm{X}^{2}$ test. All the variables having $P<0.25$ were further investigated using multivariable logistic regression analysis (Tables 3 and 4) for an association with mastitis. Due to the low numbers of mastitis-positive animals per farm (low clustering effect), an adjustment for clustering per herd was not considered critical as the logistic regression was unlikely to result in artificially low coefficients (Matope et al. 2011).

Two multivariable logistic regression models were built; one for individual animals (Table 3) and another for farm level variables (Table 4) using STATA version SE 10.0 (Stata Corp., Texas, USA). In both models, the outcome variable was the mastitis status $(0=$ negative and $1=$ positive $)$. The models were manually constructed by forward-selection, applying the maximum likelihood estimation procedure and statistical significance contribution of individual predictors (or group of predictors) using the likelihood ratio test (Matope et al. 2010; Dohoo, Martin \& Stryhn 2003). The presence of interaction between variables was checked by constructing a two-product term and forcing it into the model and examining the changes in the coefficients and $P$-values of the main effects (Matope et al. 2010). Evidence of confounding was checked by dropping one of the variables and assessing changes of the coefficients (Matope et al. 2010). Goodnessof-fit of the logistic regression models was assessed using the Hosmer-Lemeshow test, whilst predictive ability was determined using the receiver operating characteristic (ROC) curve (Dohoo et al. 2003; Matope et al. 2010).

\section{Ethical considerations}

The Ethical and the Higher Degrees Committees of the Faculty of Veterinary Science and the Department of Animal Science, Faculty of Agriculture, approved the use of animals and all protocols or procedures in this study. The objectives of this study were well explained to all participating smallholder dairy farmers who all expressed their consent to participating in the study. Questionnaire responses were given on a voluntary basis and respondents were permitted to withdraw their consent up to seven days before data submission. Standard operating procedures were used for the collection of milk samples and the dairy cows were supplied with adequate food and clean drinking water.

\section{Results \\ Descriptive statistics}

A total of 584 animals from 73 farms were tested. Of these, $21.1 \%(123 / 584)$ had mastitis, with $16.3 \%$ (95/584) and $4.8 \%(28 / 584)$ having sub-clinical and clinical mastitis respectively. Only one cow $(0.8 \%)$ with signs of clinical mastitis was negative on bacterial culture, but had a SCC $>300 \times 10^{3}$ cells $/ \mathrm{mL}$. The farm-level prevalence of mastitis was $49.3 \%$ (36/73). From the mastitis-positive cows, coagulase- 
negative staphylococci (CNS) (27.7\%), Escherichia coli (25.2\%), S. aureus (16.3\%), Klebsiella spp. (15.4\%) and Streptococcus spp. $(1.6 \%)$ were the most predominant isolates obtained. It was found that $3.2 \%$ had mixed pathogens (various combinations of pairs of E. coli, Klebsiella spp., CNS and Streptococcus spp.) and $9.0 \%$ had contaminated growths (Table 2). Cows with clinical mastitis were associated with E. coli (32.1\%), S. aureus (21.4\%), CNS (14.3\%), Klebsiella spp. (10.7\%), mixed E. coli and Klebsiella spp. (3.6\%), contaminated growths (unidentified pathogens) (14.3\%) and no bacterial isolates (3.6\%).

\section{Individual animal logistic regression model}

On univariable analysis, study area, breed, parity and history of mastitis were found to have significant associations with mastitis. However, the final logistic regression model revealed that study area and breed (Mashona, pure dairy, dairy crosses and beef crosses) were independently associated with mastitis in individual cows (Table 3).

\section{Farm level logistic regression model}

Cleaning of the teats was not included in the regression model since all farmers practiced it. On univariable analysis; post-milking teat dipping, frequency of milking, fore-milk testing, cloth use and water source were found not to be significantly associated with mastitis in herds. The final logistic regression model revealed that study areas and premilking teat dipping were independently associated with mastitis in herds (Table 4).

\section{Discussion}

The results of the present study show that utilisation of recognised pure exotic dairy breeds, such as the Holstein, Jersey or Red Dane, in the selected smallholder dairy farms is uncommon. Instead, farmers predominantly use crosses of these dairy cattle and beef breeds (mainly Mashona) for their dairy farming. This may be reflective of either the absence of a sound breeding policy for pure exotic dairy breeds by resource-limited smallholder farmers, or preference of the local beef breeds, which are better adapted to the harsh environments and offer more resistance to diseases prevalent in these areas.

In individual cows, the prevalence of sub-clinical mastitis recorded during the present study is comparable to that reported from other smallholder farming sectors

TABLE 2: Summary of the bacterial isolates from smallholder dairy cows with mastitis.

\begin{tabular}{|c|c|c|c|c|c|c|}
\hline \multirow[t]{2}{*}{ Pathogen } & \multicolumn{2}{|c|}{ Subclinical } & \multicolumn{2}{|c|}{ Clinical } & \multicolumn{2}{|c|}{ Total } \\
\hline & $n$ & $\%$ & $n$ & $\%$ & $n$ & $\%$ \\
\hline Coagulase negative staphylococci (CNS) & 30 & 24.4 & 4 & 3.3 & 34 & 27.7 \\
\hline Staphylococcus aureus & 14 & 11.4 & 6 & 4.9 & 20 & 16.3 \\
\hline Klebsiella spp. & 16 & 13.0 & 3 & 2.4 & 19 & 15.4 \\
\hline Streptococcus spp. & 2 & 1.6 & 0 & - & 2 & 1.6 \\
\hline Citrobacter spp. & 1 & 0.8 & 0 & - & 1 & 0.8 \\
\hline Klebsiella spp. and Escherichia coli & 0 & - & 1 & 0.8 & 1 & 0.8 \\
\hline Escherichia coli and CNS & 1 & 0.8 & 0 & - & 1 & 0.8 \\
\hline Klebsiella spp. and NS & 1 & 0.8 & 0 & - & 1 & 0.8 \\
\hline Streptococcus spp. and CNS & 1 & 0.8 & 0 & - & 1 & 0.8 \\
\hline Contaminated & 7 & 5.7 & 4 & 3.3 & 11 & 9.0 \\
\hline No isolates & 0 & - & 1 & 0.8 & 1 & 0.8 \\
\hline
\end{tabular}

CNS, Coagulase negative staphylococci; $n$, number of isolates.

TABLE 3: Summary of univariable and multivariable logistic regression analysis of associations between mastitis and potential risk factors for individual animals.

\begin{tabular}{|c|c|c|c|c|c|c|c|c|c|}
\hline \multirow[t]{2}{*}{ Factor } & \multirow[t]{2}{*}{ Level } & \multirow[t]{2}{*}{$N$} & \multirow[t]{2}{*}{ Prevalence $(\%)$} & \multirow[t]{2}{*}{$P$} & \multicolumn{5}{|c|}{ Multivariable logistic regression $\dagger$} \\
\hline & & & & & b & SE (b) & $P$ & OR & $95 \% \mathrm{Cl}$ \\
\hline Constant & - & - & - & - & -1.8 & 0.3 & 0.00 & - & - \\
\hline \multirow[t]{4}{*}{ Area } & 1: Marirangwe & 170 & 31.2 & 0.00 & - & - & - & 1.0 & - \\
\hline & 2: Nharira & 102 & 19.6 & & -0.3 & 0.3 & 0.34 & 0.7 & $0.4-1.4$ \\
\hline & 3: Guruve & 246 & 15.9 & & -0.6 & 0.3 & 0.04 & 0.6 & $0.4-1.0$ \\
\hline & 4: Dowa & 66 & 16.7 & & -0.5 & 0.4 & 0.24 & 0.6 & $0.3-1.4$ \\
\hline \multirow[t]{4}{*}{ Breed $\ddagger$} & 1: Mashona & 257 & 10.5 & 0.00 & - & - & - & 1.0 & - \\
\hline & 2: Dairy & 14 & 50.0 & & 1.8 & 0.6 & 0.00 & 6.3 & $2.0-20.1$ \\
\hline & 3: Dairy cross & 255 & 29.4 & & 1.1 & 0.3 & 0.00 & 3.1 & $1.9-5.1$ \\
\hline & 4: Beef cross & 58 & 24.1 & & 1.0 & 0.4 & 0.01 & 2.6 & $1.3-5.4$ \\
\hline
\end{tabular}

$N$, used as number; $\mathrm{P}$, probability value; $\mathrm{b}$, logistic regression coefficient; $\mathrm{SE}$ (b), standard error for the logistic regression coefficient; OR, Odds Ratio; $\mathrm{Cl}$, Confidence Interval.

$\dagger$, Overall data of the model: Log likelihood $=-280.4$, $L R \mathrm{chi}^{2}(6 \mathrm{~d} . f)=40.6, P=0.00$, Number of observations $=584$.

1. Breeds of cattle used in this study: Mashona, a local Sanga (Bos indicus) beef breed; Dairy breed, Jersey, Friesian or Red Dane; Dairy Cross, A crossed breed between Mashona and dairy breed; Beef cross, a crossed breed between Mashona and other unspecified beef breeds.

Beef cross, a crossed breed between Mashona and other unspecified beef $X^{2}=4.4$, d.f.8, $p=0.62$; Area under the ROC curve $=0.7$. 
TABLE 4: Summary of univariable and multivariable logistic regression analysis of associations between mastitis and potential herd-level risk factors.

\begin{tabular}{|c|c|c|c|c|c|c|c|c|c|}
\hline \multirow[t]{2}{*}{ Factor } & \multirow[t]{2}{*}{ Level } & \multirow[t]{2}{*}{$N$} & \multirow[t]{2}{*}{ Prevalence (\%) } & \multirow[t]{2}{*}{$P$} & \multicolumn{5}{|c|}{ Multivariable logistic regression $\uparrow$} \\
\hline & & & & & $\mathbf{b}$ & SE (b) & $P$ & OR & $95 \% \mathrm{Cl}$ \\
\hline Constant & - & - & - & - & -2.1 & 1.0 & 0.03 & - & - \\
\hline \multirow[t]{4}{*}{ Area } & 1: Marirangwe & 23 & 65.2 & 0.162 & - & - & - & 1.0 & - \\
\hline & 2: Nharira & 14 & 57.1 & - & -0.8 & 0.8 & 0.3 & 0.4 & $0.1-2.0$ \\
\hline & 3: Guruve & 23 & 34.8 & - & -1.5 & 0.7 & 0.04 & 0.2 & $0.1-0.9$ \\
\hline & 4: Dowa & 13 & 38.4 & - & -1.9 & 0.8 & 0.02 & 0.1 & $0.01-0.7$ \\
\hline \multirow[t]{2}{*}{ Pre-milking teat dipping not done } & 0: No & 29 & 27.6 & 0.004 & - & - & - & 1.0 & - \\
\hline & 1: Yes & 44 & 63.6 & & 1.9 & 0.6 & 0.002 & 6.7 & $2.1-22.0$ \\
\hline
\end{tabular}

$N$, used as number; P, probability value; $\mathrm{b}$, logistic regression coefficient; $\mathrm{SE}$ (b), standard error for the logistic regression coefficient; OR, Odds Ratio; Cl, Confidence Interval.

$\dagger$, Overall data of the model: Log likelihood $=-42.1, L_{R ~ c h i}{ }^{2}(4 d . f)=16.9, P=0.002$, Number of observations $=73$.

Hosmer-Lemeshow $X^{2}=2.5$, d.f.7, $p=0.8$; Area under the ROC curve $=0.8$.

(Harouna et al. 2009; Karimuribo et al. 2008; Kivaria, Noordhuizen \& Kapaga 2004). Compared to individual milk samples, composite milk samples may be less effective for the isolation of micro-organisms due to the dilution factor from uninfected quarters. The prevalence of clinical mastitis in our study $(4.8 \%)$ is within the range of other reports from smallholder dairy farms in some countries in Sub-Saharan Africa (Abera et al. 2011; Getahun et al. 2008; Kivaria et al. 2004). This provides further support of other studies in the region, which have concluded that sub-clinical mastitis is more prevalent than clinical mastitis (Almaw, Zerihun \& Asfaw 2008; Lakew, Tolosa \& Tigre 2009). This is likely to be partly influenced by virulence of the circulating bacterial strains and the levels of immunity of the cows to these pathogens. The relatively high prevalence of sub-clinical mastitis recorded in this study could possibly indicate a substantial financial loss through decreased milk production due to progressive destruction of the alveolar epithelial cells in the mammary gland (Zhao \& Lacasse 2008). Mungube et al. (2005) reported a substantial loss due to subclinical mastitis; the overall financial loss for each cow per lactation was estimated to be US $\$ 78.65$ (Tesfaye et al. 2009). However, most smallholder farmers are not well informed about the invisible losses from subclinical mastitis and do not normally recognise the condition (Mungube et al. 2004).

All of the smallholder farmers clean the teats of dairy cows with running water prior to milking, but, as observed earlier (Millogo et al. 2008), the implementation of mastitis preventive measures such as using separate drying cloths for each cow, and practicing pre- and post-milking teat dipping are noted to be infrequent amongst the farmers. A lower prevalence of both clinical and sub-clinical mastitis has been reported on farms where separate towels for teat cleaning and post-milking teat dipping were routinely practiced (Kivaria et al. 2007). Despite the fact that some of these risk factors are not found to be statistically significant in the final logistic regression model, presumably due to low sample sizes, the need to implement mastitis preventive measures such as the use of pre-milking and post-milking teat dipping cannot be overemphasised.

The isolation of CNS, S. aureus, E. coli, Klebsiella spp. and Streptococcus spp. from mastitic cows in this study supports findings from previous studies conducted in both commercial and smallholder dairy farms in Zimbabwe (Perry et al. 1987; Makaya et al. 1996; Kudinha \& Simango 2002), South Africa (Swartz, Jooste \& Novello 1984) and smallholder dairy farms in other regions of Africa (Getahun et al. 2008; Lakew et al. 2009). As observed in other studies in Zimbabwe and elsewhere (Makaya et al.1996; Kudinha \& Simango 2002; Petzer et al. 2009), sub-clinical mastitis is most commonly associated with CNS. This highlights the importance of the role of CNS in sub-clinical mastitis and that some of them are more pathogenic than is generally assumed. Therefore, the general mastitis-control programmes, such as dry cowtherapy, that take these pathogens into consideration will be more beneficial. In this study, environmental bacteria E. coli and Klebsiella spp. predominate over S. aureus in both sub-clinical and clinical mastitis; this is contrary to other reports where $S$. aureus was the most common isolate (Swartz et al. 1984; Tesfaye et al. 2009). Inadequate hygiene in the dairies in our study, especially during the rainy season when cow udders are mainly soiled due to animals lying in muddy overnight cow pens, is likely to increase the risk to infection with environmental pathogens.

Pure exotic dairy cows $(\mathrm{OR}=6.3)$, cows of dairy crosses $(\mathrm{OR}=3.1)$ and beef crosses $(\mathrm{OR}=2.6)$ are more likely to be positive for mastitis compared to the local indigenous Mashona breed. The difference in mastitis prevalence might reflect a number of general resistance characteristic attributes of the breeds, such as udder and teat morphology. Since cows in the same study area are all under similar conditions, management factors such as grazing, kraaling, milking procedures, et cetera are unlikely to influence this breed difference. Hence, it is likely that the indigenous breeds have over the years become better adapted to regional stressors than the exotic breeds. Similarly, as in previous studies (Green et al. 2008; Harouna et al. 2009), indigenous breeds (in this instance Mashona) are found to have significantly lower SCC than exotic dairy breeds and their crosses (data not shown). Therefore, due to these breed differences in levels of SCC, the diagnosis of sub-clinical mastitis, especially in indigenous cows like Mashona, may be improved by lowering the cut-off points for SCC rather than adopting the universal criteria that were designed for high-milk producing cows. 
In support of previous observations (Byarugaba et al. 2008; Getahun et al. 2008), the present study shows a progressive increase in the prevalence of mastitis with increased parity. This apparent increase in the risk of mastitis in older cows, especially after the fourth parity, could be attributed to chronic sub-clinical mastitis especially caused by hostadapted pathogens such as S. aureus (Bradley 2002). However, studies in other regions have reported higher prevalence in heifers compared to older cows; this could possibly be due to differences in management practices (McDougall et al. 2009).

Although, based on the available data, the differences in farm-level prevalence of mastitis in this study cannot be explained fully, it is likely that this can be attributed to animal husbandry practices. For instance, Marirangwe farms that keep the highest proportions of dairy crosses are associated with a higher prevalence compared to Dowa, which keep very few dairy crosses and predominantly the Mashona breed. Since the selection of the study areas was influenced by the availability of operational farms, the inclusion of more study areas across the country could have revealed differences in prevalence of mastitis according to the different agro-ecological regions. Nevertheless, considering that sub-clinical mastitis is quite prevalent and that common mastitis pathogens such as CNS, E. coli, Klebsiella spp. and $S$. aureus were isolated from all the study areas, the widespread of mastitis in smallholder dairy farms in Zimbabwe cannot be ruled out.

In conclusion, this study established an overall mean cowlevel mastitis prevalence of $21.1 \%$, where subclinical (16.3\%) is more prevalent than clinical $(4.8 \%)$ mastitis. Mastitis is found to be prevalent in all of the study areas, with a mean of $49.3 \%$. Pure exotic dairy cows, cows of dairy crosses and beef crosses have greater odds of mastitis compared to the Mashona breed. The bacteria most commonly associated with mastitis include CNS, E. coli and Klebsiella spp. and S. aureus. At farm-level, the differences in mastitis prevalence can be related to management factors like the use of pre-milking teat dipping. Further research is needed on mastitis prevalence in all regions of Zimbabwe in both smallholder and commercial dairy farms. A comparison of data between these distinct dairy farming practices is an area of further research.

\section{Acknowledgements}

This project was sponsored by the Southern African Development Community/Implementation and Coordination of Agricultural Research and Training (SADC/ICART) programme for regional training. The authors are grateful to the smallholder farmers and veterinary laboratories who participated in the study.

\section{Competing interests}

The authors declare that they have no financial or personal relationship(s) that may have inappropriately influenced them in writing this article.

\section{Authors' contributions}

D.M.P. (University of Zimbabwe) was the project leader responsible for study design and data analysis, G.M. (University of Zimbabwe) and M.N.(University of Zimbabwe) were co-leaders responsible for conceptual contributions and writing of the manuscript and S.K. (University of Zimbabwe) collected data and performed most of the experiments.

\section{References}

Abera, M., Habate, T., Aragaw, K., Asmare, K. \& Sheferaw, K., 2011, 'Major causes of mastitis and associated risk factors in smallholder dairy farms in and around Hawassa, Southern Ethiopia', Tropical Animal Health and Production 44, 1175Hawassa, Southern Ethiopia', Tropical Animal Health and Production
1179. http://dx.doi.org/10.1007/s11250-011-0055-3, PMid:22231019

Almaw, G., Zerihun, A. \& Asfaw, Y., 2008, 'Bovine mastitis and its association with selected risk factors in smallholder dairy farms in and around Bahir Dar, Ethiopia', Tropical Animal Health and Production 40, 427-432. http://dx.doi.org/10.1007/ s11250-007-9115-0, PMid:18575970

Bagnicka, E., Winnicka, A., Jozwik, A., Rzewuska, M., Strzalkowska, N., Kosciuczuk, E. et al., 2011, 'Relationship between somatic cell counts and bacterial pathogens in goat milk', Small Ruminant Research 100(1), 72-77. http://dx.doi.org/10.1016/j. smallrumres.2011.04.014

Bradley, A.J., 2002, 'Bovine mastitis: An evolving disease', The Veterinary Journal 163, $1-13$.

Byarugaba, D.K., Nakavuma, J.L., Vaarst, M. \& Laker, C., 2008, 'Mastitis occurrence and constraints to mastitis control in smallholder dairy farming systems in Uganda', Livestock Research for Rural Development 20, 1-3.

Dohoo, I., Martin, W. \& Stryhn, H., 2003, Veterinary Epidemiologic Research, AVC Inc., Charlottetown, Prince Edward Island, pp. 27-407.

Eriksson-Unnerstad, H.E., Lindberg, A., Persson-Waller, K.P., Ekman, T., Artursson, K., Nillson-Öst, M. et al., 2009, 'Microbial aetiology of acute clinical mastitis and K., Nillson-Ost, M. et al., 2009, 'Microbial aetiology of acute clinical mastitis and
agent-specific risk factors', Veterinary Microbiology 137, 90-97. http://dx.doi. agent-specific risk factors', Veterinary Microbiolog
org/10.1016/j.vetmic.2008.12.005, PMid:19155148

Getahun, K., Kelay, B., Bekana, M. \& Lobago, F., 2008, 'Bovine mastitis and antibiotic resistance patterns in Selalle smallholder dairy farms, central Ethiopia', Tropical Animal Health and Production 40, 261-268. http://dx.doi.org/10.1007/s11250007-9090-5, PMid:18557189

Green, M.J., Bradley, A.J., Medley, G.F. \& Browne, W.J., 2008, 'Cow, farm, and herd management factors in the dry period associated with raised somatic cell counts in early lactation', Journal of Dairy Science 91, 1403-1415. http://dx.doi. org/10.3168/jds.2007-0621, PMid:18349232 PMCid:2605244

Haltia, L., Honkanen-Buzalski, T., Irina Spiridonova, I., Arvi, O. \& Myllys, V., 2006, 'A study of bovine mastitis, milking procedures and management practices on 25 Estonian dairy herds', Acta Veterinaria Scandinavica 48, 1-6. http://dx.doi. org/10.1186/1751-0147-48-22, PMid:17118211 PMCid:1664578

Harouna, A., Zecchini, M., Locatelli, C. \& Scaccabarozzi, L., 2009, 'Milk hygiene and udder health in the periurban area of Hamdallaye, Niger', Tropical Animal Health and Production 41, 705-710. http://dx.doi.org/10.1007/s11250-008-9257-8, PMid:19003425

Ingalls, W., 2009, 'Somatic cells, mastitis and milk quality', viewed 05 July 2009, from http://www.jds.fass.org/cgi/content/full

International Dairy Federation, 1987, Bovine mastitis. Definition and Guidelines for Diagnosis. Bulletin 211. International Dairy Federation, Brussels, Belgium.

Karimuribo, E.D., Fitzpatrick, J.L., Swai, E.S. \& Bell, C., 2008, 'Prevalence of subclinical mastitis and associated risk factors in smallholder dairy cows in Tanzania', Veterinary Record 163, 16-21. http://dx.doi.org/10.1136/vr.163.1.16, Tanzania', Veterinar 18603630

Kivaria, F.M., Noordhuizen, J.P.T. \& Kapaga, A.M., 2004, 'Risk indicators associated with subclinical mastitis in smallholder dairy cows in Tanzania', Tropical Animal Health and Production 36, 581-592. http://dx.doi.org/10.1023/ B:TROP.0000040935.87175.bb, PMid:15560518

Kivaria, F.M., Noordhuizen, J.P.T. \& Msami, H.M., 2007, 'Risk factors associated with incidence rate of clinical mastitis in smallholder dairy cows in the Dar es Salaam region of Tanzania', Veterinary Journal 173, 623-629. http://dx.doi.org/10.1023/ B:TROP.0000040935.87175.bb, PMid:15560518

Kudinha, T. \& Simango, C. 2002, 'Prevalence of coagulase-negative staphylococci in bovine mastitis in Zimbabwe', Journal of the South African Veterinary Association 73(2), 62-65. http://dx.doi.org/10.4102/jsava.v73i2.557, PMid:12240771

Lakew, M., Tolosa, T. \& Tigre, W., 2009, 'Prevalence and major bacterial causes of bovine mastitis in Asella, south eastern Ethiopia', Tropical Animal Health and Production 41, 1573-7438. http://dx.doi.org/10.1007/s11250-009-9343-6, Production 41,
PMid:19333772

Lievaart, J., Barkema, H.W., Hogeveen, H. \& Kremer, W., 2009, 'Reliability of the bulk milk somatic cell count as an indication of average herd somatic cell count', Journal Dairy Research 76, 490-496. http://dx.doi.org/10.1017/S0022029909990264, PMid:19758478

Makaya, P.V., Aarestrup, F.M. \& Olsen, J.E., 1996, 'Distribution and antibiotic resistance patterns of common mastitis pathogens (Gram-positive cocci) in selected dairy herds of three farming dairy sectors in Zimbabwe', Zimbabwe Veterinary Journa $27(2), 65-75$.

Matope, G., Bhebhe, E., Muma, J.B., Lund, A. \& Skjerve, E., 2010, 'Herd-level factors for Brucella seropositivity in cattle reared in smallholder dairy farms of Zimbabwe', Preventive Veterinary Medicine 94, 213-221. 
Matope, G., Bhebhe, E., Muma, J.B., Lund, A. \& Skjerve, E., 2011, 'Risk factors for brucella spp. Infection in smallholder household herds', Epidemiology and infection 139, 157-164.

McDougall, S., Parker, K.I., Heuer, C. \& Compton, C.W.R., 2009, 'A review of prevention and control of heifer mastitis via non-antibiotic strategies', Veterinary Microbiology 134 (1-2), 177-185. http://dx.doi.org/10.1016/j.vetmic.2008.09.026, PMid:18986782

Muchenje, V., Chimedza-Graham, R., Sikhosana, J.L.N., Assan, N., Dzama, K. \& Chimonyo, M., 2007, 'Milk yield of Jersey x Nguni and Tuli F1 and F2 cows reared under small holder farming conditions', South African Journal of Animal Science 8, 7-10.

Mungube, E.O., Tenhagen, B.A., Kassa, T., Regassa, F., Kyule, M.N., Greine, M. et al., 2004, 'Risk factors for dairy cow mastitis in Central Highlands of Ethiopia', Tropical Animal Health and Production 36, 463-472. http://dx.doi.org/10.1023/ B:TROP.0000034999.08368.f3, PMid:15449836

Mungube, E.O., Tenhagen, B.A., Regassa, F., Kyule, M.N., Shiferaw, Y., Kassa, T. et al., 2005, 'Reduced milk production in udder quarters with subclinical mastitis and associated economic loss in crossbred dairy cows in Ethiopia', Tropical Animal Health and Production 37, 503-512. http://dx.doi.org/10.1007/s11250-0057049-y, PMid:16248222

Ngongoni, N.T., Mapiye, C., Mwale, M. \& Mupeta, B., 2006, 'Factors affecting milk production in the smallholder dairy sector in Zimbabwe', Livestock Research for Rural Development 18, 5-6.
Ngongoni, N.T., Mapiye, C., Mwale, M. \& Mupeta, B., 2007, 'Effect of supplementing a high-protein ram press sunflower cake concentrate on smallholder milk production in Zimbabwe', Tropical Animal Health and Production 39, 297-307. http://dx.doi.org/10.1007/s11250-007-9018-0 PMid: 17847825

Perry, B.D., Carter, M.E., Hill, F.W.G. \& Milne, J.A.C., 1987, 'Mastitis and milk production in cattle in a communal land of Zimbabwe', British Veterinary Journal 143, 44-50. http://dx.doi.org/10.1016/0007-1935(87)90105-9

Petzer, I.M., Karzis, J., Watermeyer, J.C., Van der Schans, T.J. \& Van Reenen, R., 2009, 'Trends in udder health and emerging mastitogenic pathogens in South African dairy herds', Journal of the South African Veterinary Association 80, 17-22.

Quinn, P.J., Carter, M.E., Markey, B.K. \& Carter, G.R., 1994, 'Clinical Veterinary Microbiology', Mosby-year book Europe limited, London.

Swartz, R., Jooste, P.J. \& Novello, J.C., 1984, 'Prevalence and type of bacteria associated with sub-clinical mastitis in Bloemfontein dairy herds', Journal of the South African Veterinary Association 55(2), 61-64.

Tesfaye, G.Y., Regassa, F.G. \& Kelay, B., 2009, 'Milk yield and associated economic losses in quarters with subclinical mastitis due to Staphylococcus aureus in Ethiopian crossbred dairy cows', Tropical Animal Health and Production 42(5), 925-931. http://dx.doi.org/10.1007/s11250-009-9509-2

Zhao, X. \& Lacasse, P., 2008, 'Mammary tissue damage during bovine mastitis: Causes and control', Journal of Animal Science 86, 57-65. http://dx.doi.org/10.2527/ jas.2007-0302 